\title{
Effect of Calcium Consumption on the Spasticity in the Spastic Rats
}

\author{
Marina Indriasari ${ }^{*}$, Hardinsyah ${ }^{1}$, Lilik Kustiyah¹, Bambang Pontjo Priosoeryanto ${ }^{2}$, \\ Ferial Hadipoetro Idris ${ }^{3}$
}

\author{
${ }^{1}$ Department of Community Nutrition, Faculty of Human Ecology, Bogor Agricultural University, Bogor, Indonesia \\ ${ }^{2}$ Department of Histopathology, Faculty of Veterinary Medicine, Bogor Agricultural University, Bogor, Indonesia \\ ${ }^{3}$ Faculty of Medicine and Health, University of Muhammadiyah, Jakarta, Indonesia \\ Email: *indriasarimarina@gmail.com
}

How to cite this paper: Indriasari, M., Hardinsyah, Kustiyah, L., Priosoeryanto, B.P. and Idris, F.H. (2019) Effect of Calcium Consumption on the Spasticity in the Spastic Rats. Food and Nutrition Sciences, 10, 37-50.

https://doi.org/10.4236/fns.2019.101004

Received: November 15, 2018

Accepted: January 11, 2019

Published: January 14, 2019

Copyright (C) 2019 by authors and Scientific Research Publishing Inc. This work is licensed under the Creative Commons Attribution International License (CC BY 4.0).

http://creativecommons.org/licenses/by/4.0/

\begin{abstract}
Spasticity is a stiff muscle condition because the muscles receive impulses continuously. Calcium ions play a role in the ability of nerves to stimulate muscle contraction. This study aimed to analyze the effect of calcium consumption on the changes of spasticity and the relation of calcium levels in the blood and muscle to the spasticity. The experimental study was conducted on 42 male Sprague-Dawley rats aged 12 - 14 weeks. The $15-\mathrm{d}$ intervention was conducted on six groups of spastic rats by administering $20 \mathrm{~g}$ of feed containing $50 \mathrm{mg}, 100 \mathrm{mg}$, and $200 \mathrm{mg}$ of calcium, it also received $100 \mathrm{mg}, 200$ $\mathrm{mg}$, and $300 \mathrm{mg}$ of calcium lactate supplementation. The experimental rats were induced with $80 \mathrm{mg} / \mathrm{kg}$ BW of Erythrocin B through the tail vein to make them spastic. This study showed a tendency of increased spasticity along with the increased dose of calcium given to the subjects. There were significant differences $(p=0.007)$ in changes in spasticity between groups. The significant differences $(\mathrm{p}=0.02)$ in changes in blood calcium levels. The Spearman's correlations test on the changes in blood calcium levels and changes in spasticity showed a positive coefficient correlation $(r=0.097)$ with a p-value of 0.54. An increase in blood calcium levels and a large decrease in spasticity were found in the group receiving $100 \mathrm{mg}$ calcium intake in $20 \mathrm{~g}$ of feed. The calcium levels in muscles had a significant correlation with spasticity ( $\mathrm{p}=0.038, \mathrm{r}=0.810)$. The calcium levels in the muscle had a strong correlation with blood calcium levels $(\mathrm{p}=0.041, \mathrm{r}=0.748)$. The biggest decrease in spasticity occurred after $100 \mathrm{mg}$ of calcium were given to the rats for 15 days, and it was considered as an optimal dose. The calcium levels in the muscles had a strong correlation with blood calcium levels and the spasticity of the spastic rats.
\end{abstract}




\section{Keywords}

Calcium, Consumption, Spasticity

\section{Introduction}

Spasticity is a stiff muscle condition because the muscles receive impulses continuously. The nerves that stimulated muscle cannot control the impulse that goes in so that the muscles continuously suffered hypertonic and caused the weakness of muscle. The condition affects to the muscle activity and ability to walk [1].

Spasticity occurred most on cerebral palsy (CP) for almost 70\% - 80\% and can caused physical disability. CP is a group of symptoms movement and posture that cause problems related to physical access that is experienced individuals in the brain development time. One of a movement disorder in CP is the stiffness in muscle because of the disruption from the central nerve that attack the upper motor neuron or usually known as spastic condition [2].

In Indonesia, CP spastic case happened 7 from $10 \mathrm{CP}$ cases and being the most case between another CP case. In the last two decades, there has been a tendency to increase $\mathrm{CP}$ prevalence due to the survival of premature babies, immature or babies born with low birth weight [3]. Riskesdas (2010) received the percentage of CP children age around 24 - 59 months old in Indonesia for $0.09 \%$ [4]. Survey in 2016 that conducted in Jakarta, Depok, and Bogor showed that $\mathrm{CP}$ children is $62.5 \%$ from 72 special needs child in 5 - 18 years old.

Calcium has an important role in a contraction muscle process. Calcium ions play a role in the ability of nerves to stimulate muscle contraction (excitability muscle nerve), adhesiveness (cohesiveness) cellular, transmission nerve impuls, and activated enzym and hormon secretion [5]. When the skeletal muscle contraction begins, $\mathrm{Ca}^{2+}$ ions are released into sarcoplasm through $\mathrm{Ca}^{2+}$ release channels (via the ryanodin receptor). These ions bind to troponin $\mathrm{C}$ and form a tropomyosin-troponin complex so that the actin and myosin shifts occur. Shifting the two filaments causes the sarcomeres to shorten so that myofibrils from muscle fibers become short. When muscle relaxation, efficiently $\mathrm{Ca}^{2+}$ ions are transported back into the sarcoplasmic reticulum by SERCA (sarco/endoplasmic $\mathrm{Ca}^{2+}$-ATPase). The sarcoplasmic reticulum will store $\mathrm{Ca}^{2+}$ which is bound to the protein calsequestrin. The $\mathrm{Ca}^{2+}$ ion release signal is preceded by the presence of depolarization in which the nerve undergoes excitatory sarcophema membrane delivered to the transverse tubule. The potential action or flow of positive negative ions on the cell membrane will extend to the sarcoplasmic reticulum and trigger the release of $\mathrm{Ca}^{2+}$ ions through the $\mathrm{Ca}^{2+}$ channel to sarcoplasm around the thick and thin myofilament [6].

In muscle relaxation there is decomposition of acetylcholine so the action potential is stopped. The work of the active transport pump $\mathrm{Ca}^{2+}$ enters $\mathrm{Ca}^{2+}$ ions 
into the sarcoplasmic reticulum. $\mathrm{Ca}^{2+}$ release channel in the closed sarcoplasmic reticulum. Decreased sarcoplasmic $\mathrm{Ca}^{2+}$ concentration makes this ion bond with troponin $\mathrm{C}$ regardless, tropomyosin-troponin complex returns to its original position to cover the active site in actin. Cross-binding is not formed and the thin filament returns to its original place [7].

Magnesium is physiologically antagonistic to calcium. Magnesium ions reduce the number of transmitters released by the motor terminal nerve, decrease the depolarization action of acetylcholine, and suppress excitability of the muscle nerve. Magnesium can compete with calcium without inducing the return of acetylcholine to reduce muscle contractility. Magnesium competes with calcium in the binding of calcium to troponin $\mathrm{C}$ and produces ATP. The sarcoplasmic reticulum actively transports calcium out of the sarcomeres so that contractions are inhibited and relaxation occurs [8].

The mechanism of spasticity according to Mukherjee \& Chakravarty is influenced by primary hyperexitability of alpha motor neurons following upper motor neuron lesions in the central nervous system so that plateau potential occurs due to continuous ionic currents [9]. Persistent $\mathrm{Ca}^{2+}$ currents can strengthen and extend the motor neuron response to cynical excitation. This inflow can produce continuous depolarization (plateau potential) when the $\mathrm{Ca}^{2+}$ channel is facilitated by noradrenergic and serotonergic innervation of motor neurons [10]. This shows that the plateau potential affected by $\mathrm{Ca}^{2+}$ ion can play a role in the pathophysiology of spasticity.

Milk is the most common consumption after rice in CP children. Milk is a food that is recommended as one of the best sources of calcium [11]. The sufficiency of calcium obtained from milk may affect CP children. The study of the effect of calcium on CP children which has an effect on spasticity has not been widely done. Therefore, research is needed to analyze the correlation between the level of calcium consumed and the level of calcium stored in blood and muscle with a degree of spasticity. Tests were carried out on spastic Sprague dawley rats to analyze the effect of calcium consumption on changes in the degree of spasticity and the relationship between calcium levels in blood and muscle with a degree of spatiality.

\section{Methods}

\subsection{Description, Place, and Time}

This experimental study is at the Faculty of Veterinary Medicine IPB for 3 months from May to July 2018. Maintenance of rats and intervention treatment as well as laboratory tests were carried out at the Faculty of Veterinary Medicine, IPB. Ethical clearance for animals was published by the LPPM (Institute for Research and Development Services) IPB.

\subsection{Materials and Tools}

The main ingredients used were calcium lactate and aquadest powder. Experi- 
mental animals are male Sprague Dawley rats aged 12 - 14 weeks weighing 200 $250 \mathrm{~g}$ as many as 42 heads. Rats were obtained from IPB Biofarmaka and received laboratory animal health certificates. Feed is made at PT. Indofeed Bogor. Materials for spastic induction used Erythrocin B solution obtained at PT. Cipta Bangun Nauli Bogor. Blood sample analysis was carried out in the integrated laboratory of IPB.

\subsection{Research Stage}

Material preparation. Feed is prepared in 2 types, which is standard feed and intervention feed. Standard feed contains calcium of $200 \mathrm{mg}$ in $20 \mathrm{~g}$ of feed (P3). Interventional feed contains calcium of $50 \mathrm{mg}$ (P1) and $100 \mathrm{mg}$ (P2) in $20 \mathrm{~g}$ of feed. Calcium solution preparations are made in 3 preparations namely calcium $100 \mathrm{mg}, 200 \mathrm{mg}$ and $300 \mathrm{mg}$ dissolved in aquadest up to $3 \mathrm{~mL}$.

Experimental rats care and Erythrocin induction B. Rats aged 10 - 12 weeks are adapted for 14 days. The rats were weighed before and after adaptation. During the adaptation period the rats have given a standard feed containing calcium of $200 \mathrm{mg}$ in $20 \mathrm{~g}$ of feed and drinking ad libitum. In the 15th day, rats were induced with Erythrocin B at a dose of $80 \mathrm{mg} / \mathrm{KgBB}$.

Assessment of spasticity. Induction is done by entering Erythrocin B which has been dissolved with $3 \mathrm{~mL}$ of aquadest through the tail vein. Shortly after induction there was a physical change in the rat, namely the change of skin and mucosa and body fluids to pink. Spasticity is evident with the value of As worth Scale 4 and passive flexion resistance of $100 \%$. Spasticity is assessed before and after the intervention begins the next day.

Intervention in rats. A total of 42 rats were divided into 6 groups including K1 with P1 (feed contain $50 \mathrm{mg}$ calcium), K2 administration with P2 (feed contain $100 \mathrm{mg}$ of calcium), K3 with P3 (feed contain $200 \mathrm{mg}$ calcium), K4 with P3 (feed contain $200 \mathrm{mg}$ calcium) and $100 \mathrm{mg}$ calcium supplementation, K5 with P3 (feed contain $200 \mathrm{mg}$ calcium) and $200 \mathrm{mg}$ calcium supplementation and $\mathrm{K} 6$ with P3 (feed contain $200 \mathrm{mg}$ calcium) and $300 \mathrm{mg}$ calcium supplementation. Calcium supplementation is given through sonde. The intervention was carried out for 15 days.

Measurement of calcium levels in blood. Blood is taken through the tail vein before and after intervention as much as $1 \mathrm{~mL}$. Rats weighed before and after intervention.

Assessment of muscle calcium. The left gastrocnemius muscle is excised and taken as much as $0.5 \mathrm{~g}$ to measure the level of calcium in the muscle.

\subsection{Processing and Analysis of Data}

Stages of data analysis of spasticity, blood calcium of rats before and after intervention as well as muscle calcium levels after the intervention were carried out by Saphiro-Wilk normality test because the sample $<50$. Data distribution was declared normal if $\mathrm{p}>0.05$. Analysis of different tests between groups using the 
Anova test if the data distribution is normal. The Kruskal-Willis test is used when the data distribution is not normal. There are significant differences in the effect of different treatments ( $\mathrm{p}<0.05)$, then it will be followed by Duncan's test. Correlation analysis between variables using the Spearman test.

\section{Results and Study}

\subsection{Feed Composition}

Feed is consumed by the subject for 24 hours as much as 20 grams by drinking as much as ad libitum. In this study feed was made with the composition of water, ash, protein, fat, carbohydrates and fiber as macro nutrients. Minerals contained in feed include calcium and magnesium. Feed composition was analyzed by proximate test. In Table 1 , the composition of the feed given to the subject is explained.

Table 1 shows that the composition of carbohydrates is the greatest in each feed and followed by protein. The main function of carbohydrates is as a source of energy in the body. When the body is in a condition of lack carbohydrates, the body will take protein as one of the reserves energy sources. If that happens, it will cause the protein function to be not optimal. Carbohydrate needs are very good in optimizing the protein function. When physically active people don't get enough carbohydrates, the body will use protein to carry out the necessary muscle functions, including muscle building. In a state of spasticity, protein involvement during nitric oxide (NO) formation occurs due to activation of the nitric oxide synthase (NOS) enzyme. Enzyme activation occurs due to an increase in calcium in cells due to depolarization in muscles that experience spasticity [12].

Figure 1 shows a higher calcium content than magnesium content in every feed. Increased calcium content is accompanied by an increase in magnesium content in feed. Calcium plays a role in the interaction of proteins in the muscles, namely actin and myosin when the muscles contract. If calcium in the blood is less than normal, then the muscles cannot relax after contractions cause muscle stiffness and if contractions occur excessively and are affected by central nervous disorders, spasticity will occur due to hyperexitation [13].

Magnesium plays a role in muscle relaxation and contraction. Magnesium is used to regulate muscle and nerve control. In nerve cells, magnesium acts as a chemical barrier gate, as long as there is enough magnesium available, calcium will not quickly enter nerve cells and activate nerves. This barrier gate by magnesium helps keep the nerves relaxed. If the magnesium intake is low, the nerve cells become overactive. When some nerve cells are too active, it sends messages to the muscles and causes the muscles to contract continuously so that it can cause muscle fatigue. Magnesium is responsible for the production and transportation of energy by working as a co-factor with other enzymes to aid digestion and absorption of protein, carbohydrates and fats [14].

The content of carbohydrates and proteins in the feed appear to be inversely proportional, the higher the calcium content, the higher the protein content and 
Table 1. Subject feed composition.

\begin{tabular}{|c|c|c|c|c|}
\hline Composition & \multicolumn{2}{|c|}{$\mathrm{P} 1$} & $\mathrm{P} 2$ & Methods \\
\hline Water $(\% \mathrm{w} / \mathrm{w})$ & 10.93 & 10.22 & 9.88 & AOAC(2012)930.15 \\
\hline Ash $(\% w / w)$ & 7.62 & 7.78 & 8.49 & AOAC(2012)942.05 \\
\hline Protein $(\% w / w)$ & 16.32 & 18.98 & 26.88 & IK.LP-04.5-LT-1.0 \\
\hline Protein $(\% w / w)$ & 5.01 & 4.74 & 3.85 & AOAC(2012)991.36 \\
\hline Carbohydrates(\%w/w) & 59.86 & 58.20 & 52.30 & IK.LP-04.3-LT-1.0 \\
\hline Fiber $(\% \mathrm{w} / \mathrm{w})$ & 3.59 & 3.29 & 3.06 & IK.LP-04.13-LT-1.0 \\
\hline Calcium $(\mathrm{mg} / \mathrm{Kg})$ & 3155.97 & 5361.82 & 6749.91 & $\operatorname{AOAC(2012):999.11}$ \\
\hline Magnesium (mg/Kg) & 837.52 & 1079.22 & 6749.91 & AOAC(2012):999.11 \\
\hline
\end{tabular}

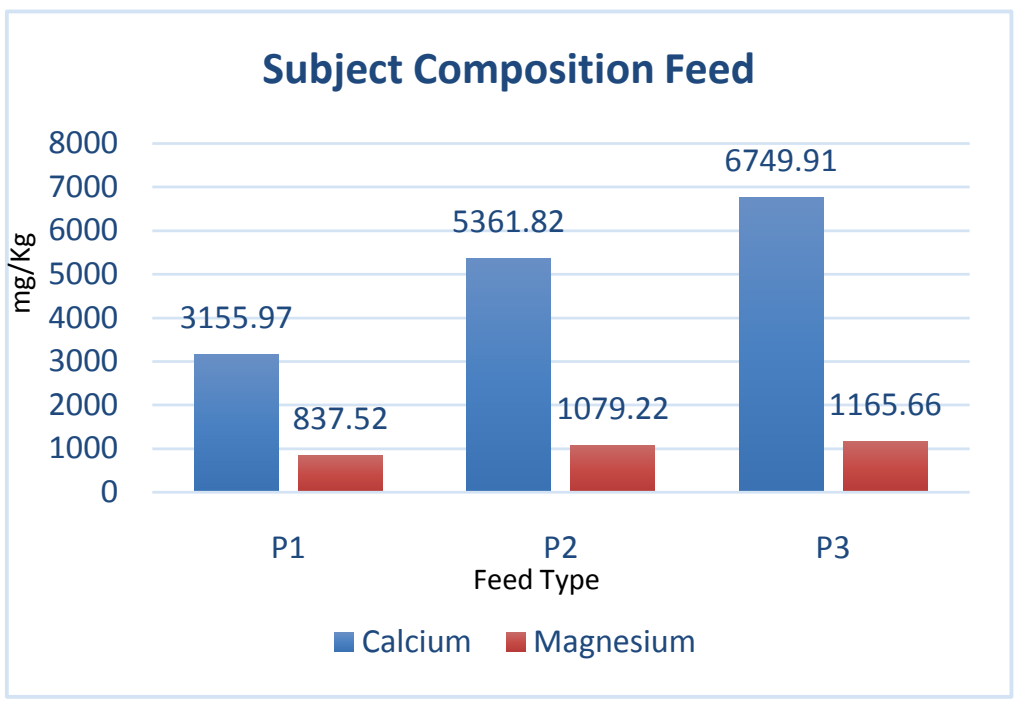

Figure 1. Calcium and Magnesium content in Feed.

the lower the carbohydrate content. Conversely, the lower the calcium content in feed, the lower the protein content and the greater the carbohydrate content in feed. This shows the relationship between protein and calcium. In the process of calcium metabolism in enterocytes it is necessary to have a calcium binding protein synthesized by other active metabolites such as vitamin $\mathrm{D}$ in the intestinal lumen [15].

\subsection{Degree of Subject Spasticity}

Shortly after being induced in the form of Erythrocin B through the tail vein as much as $1 \mathrm{~mL}$ with a dose of $80 \mathrm{mg} / \mathrm{Kg} \mathrm{BB}$, the average subject experienced As worth Scale with muscle resistance in the upper and lower limbs by $100 \%$. Pink physical appearance on the lining of the eyes, ears and skin and body fluids such as urine and feces. Table 2 shows the mean values of rat spasticity before and after the intervention and changes. Assessment of spasticity is carried out by passively moving the flexion of the extension of the four subject limbs and assessed the percentage of muscle resistance. 
Table 2. Average value of subject spasticity.

\begin{tabular}{cccc}
\hline Groups & $\begin{array}{c}\text { Before } \\
\text { intervention }\end{array}$ & $\begin{array}{c}\text { After } \\
\text { intervention }\end{array}$ & $\Delta$ \\
\hline K1 & $67.86 \pm 12.20$ & $57.14 \pm 12.20$ & $-10.72 \pm 13.36$ \\
K2 & $71.43 \pm 9.45$ & $57.14 \pm 12.20$ & $-14.29 \pm 13.36$ \\
K3 & $60.72 \pm 13.36$ & $60.71 \pm 13.36$ & $0.00 \pm 20.41$ \\
K4 & $53.57 \pm 9.45$ & $64.29 \pm 13.36$ & $10.71 \pm 13.36$ \\
K5 & $60.72 \pm 13.36$ & $64.29 \pm 13.36$ & $3.57 \pm 17.25$ \\
K6 & $53.57 \pm 9.45$ & $64.29 \pm 28.35$ & $17.85 \pm 12.20$ \\
\hline
\end{tabular}

Figure 2 shows the tendency of increasing spasticity by the addition of calcium doses intake in the subject. These results are in line with Ho et al. [16] research which concluded that spastic occurrence in paraplegia that associated with dysregulation of calcium or due to changes in calcium homeostasis in the body. Shamseldin et al. [17] shows that the phenotype of neurodevelopmental disorder is one of the symptoms of spasticity related to disruption of intracellular calcium homeostasis.

Abnormal distribution of the variable spasticity value $(\mathrm{p}=0.000)$ in more than 2 unpaired groups because each group with different subjects and treatments used the Kruskal-Wallis test. In the group before intervention, there were significant differences $(\mathrm{p}=0.039)$ and after the intervention there were significant differences $(p=0.000)$. Changes in spasticity between groups have significant differences $(p=0.007)$. The results of this study concluded that between groups there were significant differences in the value of spasticity at the time before and after the intervention and on changes in the value of spasticity before and after the intervention.

Since 1940, calcium ions are believed to play a role in regulating muscle contraction. Ebashi showed that the effect of $\mathrm{Ca}^{2+}$ was mediated by Troponin and Tropomiosin. $\mathrm{Ca}^{2+}$ regulates muscle contraction with processes mediated by Troponin and Tropomiosin. Actomyosine extracted directly from the muscle contains bonds with troponin and tropomyosin, contracting due to ATP only if $\mathrm{Ca}^{2+}$ is present. The presence of troponin and tropomyosin in the actomyosin system increases the sensitivity of the system to $\mathrm{Ca}^{2+}[18]$.

Striated muscle movements under command or a control called motor nerve impulses. Nerve impulses release $\mathrm{Ca}^{2+}$ from the sarcoplasma reticulum (SR). All sarcomeres in a muscle will receive a signal to contract so that the muscle can contract as a whole. The electrical signal is delivered to the sarcoplasmic reticulum. SR is a system of flat, membrane-shaped vesicles, and originates from the endoplasmic reticulum. The system wraps each miofibril into a knit shape. Muscles can contract due to stimulation. Generally the muscles contract not because of one stimulus, but because of a series of sequential stimuli. The second stimulus strengthens the first stimulation and the third stimulates the second stimulation, resulting in hyperexitation resulting in maximum tension or tone. This explains the occurrence of a state of spasticity [19]. 


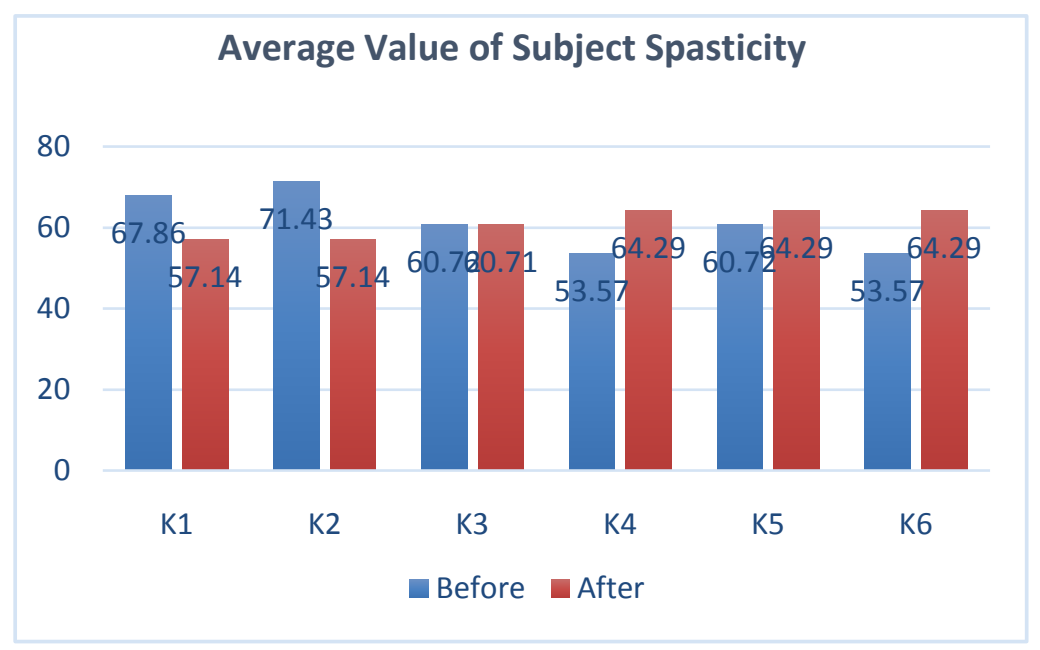

Figure 2. Spasticity value before and after intervention.

\subsection{Subject's Blood Calcium Level}

This study found that there was a decrease in the level of calcium in the blood in each group except in $\mathrm{K} 2$ which got results with increased blood calcium levels after intervention. The mean level of calcium in the blood before and after the intervention in units of $\mathrm{mg} / \mathrm{dL}$ and its changes is illustrated in Table 3.

Figure 3 shows that giving a calcium intake of $500 \mathrm{mg}$ results in a decrease in calcium levels in the blood, as well as giving $50 \mathrm{mg}$ of calcium there is a decrease in blood calcium levels. Normality test with Saphiro-Wilk obtained results on variable blood calcium levels before intervention with abnormal data distribution ( $p=0.049)$. Variable calcium levels after intervention with normal distribution $(\mathrm{p}=0.128)$ also on changes in blood calcium levels have normal data distribution $(p=0.904)$. Anova test was conducted to obtain the significance value of differences in treatment between groups with normal distribution and obtained $\mathrm{p}=0.02$ for changes in blood calcium levels, indicating a significant difference in changes in blood calcium levels between groups in this study. Anova test was also carried out in the group after intervention and the results were significantly different between groups $(\mathrm{p}=0.001)$. In the group before intervention Kruskal-Wallis test was conducted because the data distribution was not normal and the results were not significant $(\mathrm{p}=0.355)$.

Calcium has two important physiological roles, namely maintaining the structural integrity of the skeleton and contributing much to important cell processes. In extracellular and cytosolic fluids, ionized calcium $\left(\mathrm{Ca}^{2+}\right)$ plays an important role in various processes in cells. Calcium is an important substance in cell membranes that affects permeability and electrical charge. Plasma calcium is in three forms: binds to protein (albumin), binds to small ligands (phosphate, citrate, sulfate), and $\mathrm{Ca}^{2+}$ ionized calcium. Ionized calcium in the plasma is physiologically active and plays an important role in determining hypocalcemia or hypercalcaemia. Ionized calcium levels in extracellular fluid are maintained at homeostasis in the normal range of around $9-10.5 \mathrm{mg} / \mathrm{dl}$. This situation is 
Table 3. The average level of calcium in the subject's blood.

\begin{tabular}{cccc}
\hline Groups & $\begin{array}{c}\text { Before } \\
\text { intervention }\end{array}$ & $\begin{array}{c}\text { After } \\
\text { intervention }\end{array}$ & $\Delta$ \\
\hline K1 & $17.37 \pm 2.83$ & $12.05 \pm 2.69$ & $-5.33 \pm 3.55$ \\
K2 & $14.90 \pm 2.95$ & $17.44 \pm 3.34$ & $2.54 \pm 4.01$ \\
K3 & $15.06 \pm 2.76$ & $11.34 \pm 2.91$ & $-3.71 \pm 4.98$ \\
K4 & $13.81 \pm 2.92$ & $10.30 \pm 1.65$ & $-3.51 \pm 2.76$ \\
K5 & $15.69 \pm 3.2$ & $14.30 \pm 1.48$ & $-1.39 \pm 4.34$ \\
K6 & $16.24 \pm 4.47$ & $10.21 \pm 5.20$ & $-4.19 \pm 5.34$ \\
\hline
\end{tabular}

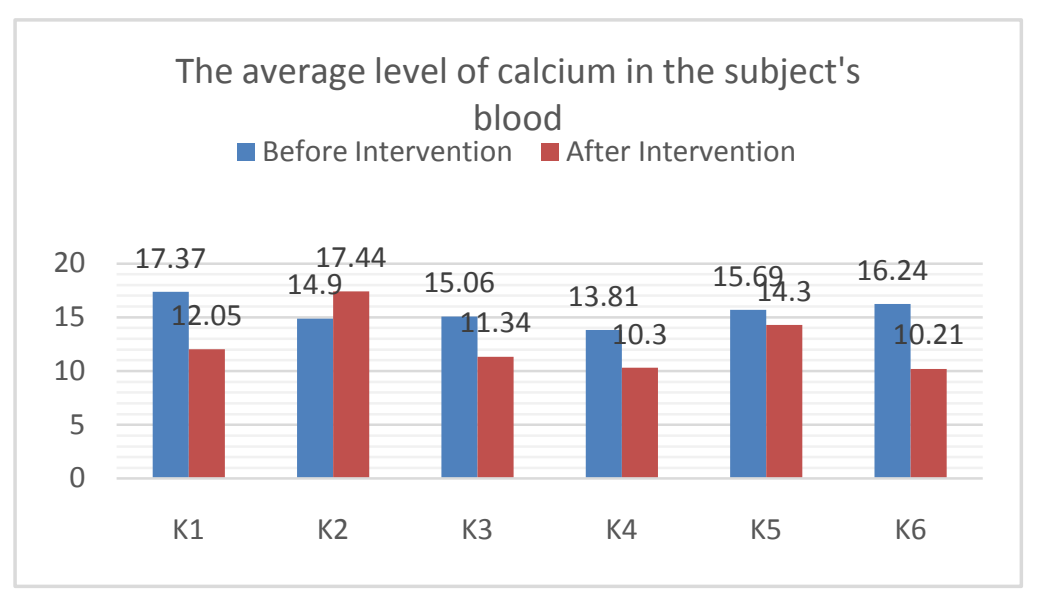

Figure 3. The average level of calcium in the subject's blood before and after intervention.

maintained by an effective balance of bone formation and bone resorption, calcium absorption, and calcium excretion. The main place of regulation takes place in the bones, kidneys, and gastrointestinal tract under the control of three hormones, namely parathyroid hormone, calcitonin, and calcitriol [20].

Spearman correlation test between changes in blood calcium levels with changes in spasticity showed a positive correlation coefficient of 0.097 with $\mathrm{p}=$ 0.54 , so it can be concluded that there is no significant correlation between changes in blood calcium levels with changes in spasticity in rats.

Table 4 shows that $\mathrm{K} 2$ with P2 intake containing calcium $100 \mathrm{mg}$ in $20 \mathrm{~g}$ of food there is an increase in blood calcium levels and a large decrease in spasticity. This shows that a dose of $100 \mathrm{mg}$ of calcium which is half the standard dose of feed (200 mg of calcium) can be used as a reference for decreasing the most optimal spasticity.

In the body there is a system of mechanisms to maintain the balance of certain substances in the blood, especially those referred to as homeostasis. Calcitriol, calcitonin and parathyroid hormones regulate body calcium. Special cells in the kidneys produce calcitriol, a form of vitamin $\mathrm{D}$, when the blood calcium level is too low. This hormone increases the body's calcium absorption from food and the release of calcium from bone. Parathyroid hormone (PTH), secreted by the 
Table 4. Average changes in blood calcium levels and subject spasticity.

\begin{tabular}{ccc}
\hline Groups & Changes in Blood Calcium Level & Changes of Spasticity \\
\hline K1 & $-5.33 \pm 3.55$ & $-10.72 \pm 13.36$ \\
K2 & $2.54 \pm 4.01$ & $-14.29 \pm 13.36$ \\
K3 & $-3.71 \pm 4.98$ & $0.00 \pm 20.41$ \\
K4 & $-3.51 \pm 2.76$ & $10.71 \pm 13.36$ \\
K5 & $-1.39 \pm 4.34$ & $3.57 \pm 17.25$ \\
K6 & $-4.19 \pm 5.34$ & $17.85 \pm 12.20$ \\
\hline
\end{tabular}

parathyroid gland and increases calcium levels in the blood by stimulating bone to release calcium, stimulates kidney cells to reclaim calcium from the urine before excretion, and increase intestinal calcium absorption. Calcitonin hormones reduce calcium levels in the blood. Its production is stimulated by too high levels of calcium in the blood. Calcitonin hormone production by $\mathrm{C}$ cells from the thyroid gland and works by suppressing the release of calcium from the bone, reducing calcium absorption in the intestine and liver and kidneys [21].

\subsection{Relationship between Muscle and Blood Calcium Levels with Subject Spasticity}

In muscles that experience spasticity there is continuous contraction so that the muscles become stiff. Muscles receive continuous impulses due to abnormalities in the central nervous system so that the muscles are unable to control the incoming impulses so that the muscles experience hypertonus. Spastic muscles increase muscle tone or muscle resistance or hypertonus [22].

Muscle contraction, especially skeletal muscle, is driven by nerve impulses that stimulate release of $\mathrm{Ca}^{2+}$ from the sarcoplasmic reticulum. When sarcomere membranes are excited by nerve impulses, the signals generated are channeled into the $\mathrm{T}$ tubular system and the channel of release of $\mathrm{Ca}^{2+}$ ions in the surrounding sarcoplasmic reticulum opens rapidly and releases $\mathrm{Ca}^{2+}$ ions into sarcoplasm from the sarcoplasmic reticulum. The concentration of $\mathrm{Ca}^{2+}$ ions in sarcoplasm increases rapidly to $10-5 \mathrm{~mol} / \mathrm{L}$. Increased concentration of $\mathrm{Ca}^{2+}$ ions signals muscle contraction through the movement of protein precursors bound to actin filaments namely tropomyosin and troponin [23].

Table 5 shows the average value of muscle spasticity, calcium levels in the gastroknemius muscles and blood calcium levels after 15 days of intervention in 6 groups of rats which will be tested by correlation with the Spearman test. Correlation test between levels of muscle calcium with subject spasticity obtained $\mathrm{p}$ $=0.038$, meaning that there is a significant correlation with the value of $r=0.810$ which indicates that the relationship between levels of calcium muscle with subject spasticity has a strong correlation. Correlation test between levels of calcium muscle with blood calcium levels obtained a value of $\mathrm{p}=0.041$, indicating a significant correlation with the value of $r=0.748$ which shows a strong correlation between levels of calcium muscle with blood calcium levels. 
Table 5. Average values of muscle spasticity and levels of muscle and blood calcium.

\begin{tabular}{cccc}
\hline Kelompok & Nilai spastisitas otot $(\%)$ & Kadar kalsium otot $(\mathrm{ppm})$ & Kadar kalsium darah $(\mathrm{mg} / \mathrm{dl})$ \\
\hline K1 & $57.14+12.20$ & $96.73+42.56$ & $12.05+2.69$ \\
K2 & $57.14+12.20$ & $118.33+63.29$ & $17.44+3.34$ \\
K3 & $60.71+13.36$ & $86.49+56.49$ & $11.34+2.91$ \\
K4 & $64.29+13.36$ & $85.04+36.71$ & $10.30+1.65$ \\
K5 & $64.29+13.36$ & $129.57+89.23$ & $14.30+1.48$ \\
K6 & $64.29+28.35$ & $124.12+143.17$ & $10.21+5.20$ \\
\hline
\end{tabular}

Spasticity is a motor disorder characterized by an increase in muscle tone due to the hyperexitability of reflex stretching as part of upper motor neuron syndrome. Reflex hyperexitability occurs due to dissociation or disintegration of motor responses to sensory input. Spasticity occurs due to lesions in the descending corticospinal system causing excessive contraction between the agonist and antagonistic muscles due to abnormal patterns of supraspinal pathway commands [24].

Calcium also triggers contraction by reacting to regulator proteins which can cause the interaction of actin-myosin filaments. Tropomyosin movement is also controlled by calcium which binds to troponin. The presence of troponin and tropomyosin in the actomyosin system increases the sensitivity of the system to $\mathrm{Ca}^{2+}$. Nerve impulses that occur will arrive at the neuromuscular junction and are immediately delivered to each sarcomere so that the muscle bundle will receive a signal to contract [25].

Ionized calcium is calcium that is bound to other minerals. Calcium is also bound to proteins such as albumin. Ionized calcium is known as free calcium which is the most active form. Physiology of calcium through intracellular and extracellular activities that are interrelated. Intracellular calcium is an important regulator of various cellular events, including muscle contraction, nerve signals to muscles, secretion of hormones, glycogen metabolism, and cell division. Extracellular calcium not only provides a stable supply of calcium for intracellular use but also plays an important role in membrane clotting and integrity. Extracellular calcium, including intravascular calcium, accounts for about $0.1 \%$ of total body calcium. Extracellular calcium concentration is five times more than intracellular concentration [26].

Calcium in the circulatory system, extracellular fluid, muscles and other tissues is very important for mediating vascular contractions and vasodilation, muscle function, nerve transmission, intracellular signals, and hormone secretion. Calcium metabolism is largely regulated by the parathyroid hormone system. The rapid release of minerals from the bone is very important to maintain sufficient levels of ionized calcium in the serum. Maintaining ionized calcium levels circulating in the circulation is very important for the body to function normally, and control of serum calcium levels is maintained through the endo- 
crine system, which is the glandular system that secretes hormones and is influenced by several control factors and feedback mechanisms [15].

\section{Conclusions}

Optimal dose of daily calcium intake in spastic rats obtained at $100 \mathrm{mg}$ is half of the standard dose contained in the daily diet. The biggest decrease in spasticity occurs after 15 days, given $100 \mathrm{mg}$ of calcium in a daily feed of $20 \mathrm{~g}$. The decrease in spasticity is accompanied by an increase in calcium levels in the blood. There are significant differences in changes in spasticity between groups. There is a strong correlation between levels of muscle calcium and blood calcium levels as well as spastic rat spasticity. Increased calcium in the blood includes calcium stored in the sarcoplasmic reticulum and the absence or reduced release of calcium into the myofibril can reduce the occurrence of spasticity. Increased calcium in the muscles due to the release of calcium ions into the myofibril causes spasticity to be more pronounced. The increase calcium level in blood allows the increasing release of calcium ions into the myofibrils that can allow spasticity [26]. There is the need for clinical studies to find out the benefits of consuming calcium-containing milk in children with symptoms of spasticity.

\section{Conflicts of Interest}

The authors declare no conflicts of interest regarding the publication of this paper.

\section{References}

[1] Goldstein, E.M. (2001) Spasticity Management: An Overview. Journal of Child Neurology, 16, 16-23. https://doi.org/10.1177/088307380101600104

[2] Pandyan, A.D., Gregoric, M., Barnes, M.P., Wood, D., Van Wijck, F., Burridge, J., Hermens, H. and Johnson, G.R. (2005) Spasticity: Clinical Perception, Neurological Realities and Meaningful Measurement. Disability and Rehabilitation, 27, 2-6. https://doi.org/10.1080/09638280400014576

[3] Idris, F.H. (2002) Medical Rehabilitation of Cerebral Palsy. Training of Indonesia Peditriacian of Medical Rehabilitation, Semarang.

[4] Health Research and Development Agency of the Republic of Indonesia (2010) Basic Health Research Results 2010. Health Research and Development Agency of the Republic of Indonesia, Jakarta.

[5] Suhardjo (2000) Food and Nutrition Planning. Bumi Aksara, Jakarta.

[6] Gartner, P. and Hiatt, J.L. (2007) Muscle. Color Textbook of Histology, 3rd Edition, Saunders Elsevier, Philadelphia.

[7] Junqueira, L.C. and Carneiro, J. (2005) Muscle Tissue. Basic Histology Text \& Atlas, 7th Edition, McGraw-Hill, New York.

[8] Rossier, M.F. (2016) T-Type Calcium Channel: A Privilage Gate for Calcium Entry and Control of Adrenal Steroidogenesis. Frontiers in Endocrinology (Lausanne), 7, 43. https://doi.org/10.3389/fendo.2016.00043

[9] Mukherjee, A. and Chakravarty, A. (2010) Spasticity Mechanism for the Clinician. 
Frontiers in Endocrinology, 1, 1-10. https://doi.org/10.3389/fneur.2010.00149

[10] Li, Y., Li, X., Harvey, P.J. and Bennett, D.J. (2004) Effect of Baclofen on Spinal Reflexes and Persistent Inward Currents in Motoneurons of Chronic Spinal Rats with Spasticity. Journal of Neurophysiology, 92, 2694-2703.

https://doi.org/10.1152/jn.00164.2004

[11] Rozenberg, S., Body, J., Bruyere, O., Bergmann, P., Brandi, M.L., Cooper, C., Devogelaer, J., Gielen, E., Goemaere, S., Kaufman, J., et al. (2016) Effects of Dairy Products Consumption on Health: Benefits and Beliefs-A Commentary from the Belgian Bone Club and The European Society for Clinical and Economic Aspescts of Osteoporosis, Osteoarthritis and Musculoskreletal Diseases. Calcified Tissue International, 98, 1-17. https://doi.org/10.1007/s00223-015-0062-x

[12] McClelland, S., Teng, Q., Benson, L.S. and Boulis, N.M. (2007) Motor Neuron Inhibition-Based Gene Therapy for Spasticity. American Journal of Physical Medicine \& Rehabilitation, 86, 412-421. https://doi.org/10.1097/PHM.0b013e31804a83cf

[13] Price, S.A. and Wilson, L.M. (2006) Pathophysiology: Clinical Concepts of Disease Processes. 6th Edition, Vol. 1, EGC, Jakarta.

[14] Guerrera, M., Volpe, S.L. and Mao J. (2009) Therapeutic Uses of Magnesium. American Family Physician, 80, 157-162.

[15] Peacock, M. (2010) Calcium Metabolism in Health and Disease. Clinical Journal of the American Society of Nephrology, 5, S23-S30. https://doi.org/10.2215/CJN.05910809

[16] Ho, P.W., Pang, S.Y., Li, M., Tse, Z.H., Kung, M.H., Sham, P.C. and Ho, S.L. (2015) PMCA4 (ATP2B4) Mutation in Familial Spastic Paraplegia Causes Delay in Intracellular Calcium Extrusion. Brain and Behavior, 5, e00321. https://doi.org/10.1002/brb3.321

[17] Shamseldin, H.E., Alasmari, A., Salih, M.A., Samman, M.M., Mian, S.A., Alshidi, T., Ibrahim, N., Hashem, M., Faqeih, E., Al-Mohanna, F., et al. (2017) A Null Mutation in MICU2 Causes Abnormal Mitochondrial Calcium Homeostasis and a Severe Neurodevelopmental Disorder. Brain, 140, 2806-2813. https://doi.org/10.1093/brain/awx237

[18] Ebashi, S. (1972) Calcium Ions and Muscle Contraction. Survey of Japanese Science, 240, 217-218. https://doi.org/10.1038/240217a0

[19] Syaifuddin (2006) Anatomy of Physiology for Nursing Students. EGC, Jakarta.

[20] Bruder, J.M., Guise, T.A. and Mundy, G.R. (2001) Mineral Metabolism. In: Felig, P. and Frohman, L.A., Eds., Endocrinology \& Metabolism, 4th Edition, McGraw-Hill, New York, Vol. 22, 1079-1159.

[21] Deftos, L.J. (2001) Immunoassays for PTH and PTHrP. In: Bilezikian, J.P., Marcus, R. and Levine, A., Eds., The Parathyroids, 2nd Edition, Elsevier, Amsterdam, Chapter 9, 143-165. https://doi.org/10.1016/B978-012098651-4/50011-0

[22] Rengachary, S.S. and Wilkins, R.H. (1994) Principles of Neurosurgery. Mosby, London.

[23] McComas, A.J. (1996) Skeletal Muscle, Form and Function. Human Kinetics, Champaign, 106-108.

[24] Thibaut, A., Chatelle, C., Ziegler, E., Bruno, M., Laureys, S. and Gosseries, O. (2013) Spasticity after Stroke: Physiology, Assessment and Treatment. Brain Injury, 27, 1-13. https://doi.org/10.3109/02699052.2013.804202

[25] Berchtold, M.W., Brinkmeier, H. and Muntener, M. (2000) Calcium Ion in Skeletal 
Muscle: Its Crucial Role for Muscle Function, Plasticity, and Disease. Physiological Reviews, 80, 1215-1265. https://doi.org/10.1152/physrev.2000.80.3.1215

[26] Guyton, A.C. and Hall, J.E. (2001) Textbook in Medical Physiology. 10th Edition, W.B. Saunders, Philadelphia, PA. 